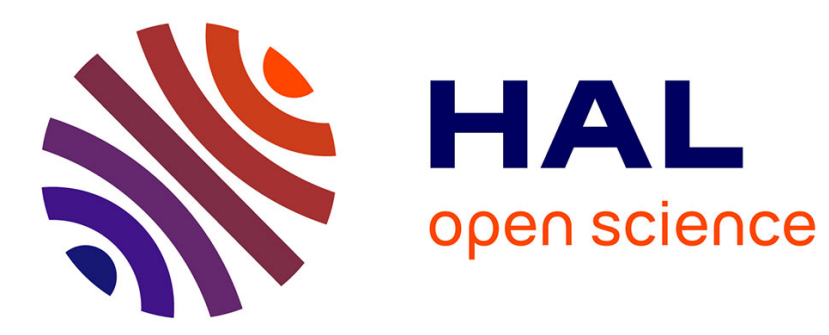

\title{
Social Gap: the double meaning of Overlooking
}

\author{
Sophie Duchesne
}

\section{To cite this version:}

Sophie Duchesne. Social Gap: the double meaning of Overlooking. Sophie Duchesne; Elizabeth Frazer; Florence Haegel; Virginie Van Ingelgom. Citizens' reactions to European integration compared:

Overlooking Europe, Palgrave Macmillan, pp.65-95, 2013. halshs-00794386

\section{HAL Id: halshs-00794386 \\ https://shs.hal.science/halshs-00794386}

Submitted on 25 Feb 2013

HAL is a multi-disciplinary open access archive for the deposit and dissemination of scientific research documents, whether they are published or not. The documents may come from teaching and research institutions in France or abroad, or from public or private research centers.
L'archive ouverte pluridisciplinaire $\mathbf{H A L}$, est destinée au dépôt et à la diffusion de documents scientifiques de niveau recherche, publiés ou non, émanant des établissements d'enseignement et de recherche français ou étrangers, des laboratoires publics ou privés. 
CH. 3 - Social gap: the double meaning of 'overlooking'

Sophie Duchesne

Published in "Citizens' reactions to European integration compared: Overlooking Europe"

S.Duchesne, E. Frazer, F.Haegel and V.Van Ingelgom, Palgrave Macmillan, 2013 (65-95).

Introduction

European studies acknowledged what is usually considered the elitist bias of European integration long before Fligstein, in Euro-clash, concluded that:

'Europe as a social and cultural project is clearly a social class project. The class aspects of

European economic and social integration explain some of the anti-EU national politics that have emerged.' (Fligstein, 2010: 251)

The bias consists first of the unequal benefits that different social groups gained from market integration and from the corollary reforms. Second it consists of the persistently unequal support that citizens give to the European political system, depending on their social class, whether this is measured primarily by income, wealth, occupational status, or educational attainment. (Belot 2002, Cautrès et Grunberg 2007)

Fligstein's conclusions, however, are not as straightforward as the above quotation suggests. He does not simply mean that because European integration is a class project, it is logically opposed by those who benefit less or even suffer from it. The Euro-clash thesis is more sophisticated. It first confirms, by analysis of extensive socio-economic data, that those who benefit from integration are managers, executives, some white collars and technical workers, the highly educated, the wealthy, and the young. It goes on to show that these people, because of the increasing mobility and communication capacity offered by the EU, have developed new relationships with their fellow Europeans, through work and leisure. As a consequence, and in conformity with the theoretical framework that Deutsch developed 
regarding nation building (Deusch 1969) they tend to feel that they are Europeans at a much greater rate than do others - blue collar workers, the less educated, the poor and the old. These groups remain embedded in national societies, and more than ever 'feel national' or identify with their nations. These differences in feeling can become confrontational: they can translate into opposing political wills and directions in political action. According to Fligstein, citizens who are positioned in the middle classes, and who benefit only partially from the new opportunities offered by integration, also tend to display 'middling' identities. They feel both national and European. They, thus, are destined to be the arbitrators of the Euro-clash.

The idea that identity and affect play a central role in public opinion of the EU has become widespread. By identity is understood the self-identification of people as members of a political community, in this case as national citizens or as European. By affect is meant the range of feelings associated with identification, including in particular in-group preference. Hooghe and Mark's leading work supports this thesis. They consider that exclusive national identity - measured in Eurobarometer by way of the question: do you in the near future see yourself as only (national), (national) and European, European and (national) or European only? - is a key element in European politics which can be, and is, mobilized by political entrepreneurs and parties against the EU. In the article that develops the influential notion of 'constraining dissensus', they conclude that

'the European Union is part of a system of multi-level governance which is driven by identity politics as well as by functional and distributional pressures. Conceptions of the political community are logically prior to the decision about the regime form. In the European Union, the debate about who 'we' are is politically charged and causally influential.' (Hooghe and Marks, 2009: 23)

So the elite bias that has accompanied European integration from the founding era is now interpreted as both interest and identity grounded, and is considered to be of paramount importance for the future of Europe. Working class people are expected to be (potentially) against further integration, not only because they feel economically and socially threatened by the changes that EU decisions bring to their lives, but also because they feel emotionally attached to their nation and do not want its sovereignty 
limited. Evidence for this is mainly taken from Eurobarometer survey analysis, and based on social identity theory (Herrmann, Risse and Brewer 2004). ${ }^{\mathrm{i}}$ But Eurobarometer, like any other survey, is not best suited for the analysis of identity or affect.

Our own project was not designed specifically for identity analysis. Political sociologists have used focus groups this way, though. Gamson, one of the first authors to reintroduce focus groups into the discipline (Morgan 1996) wanted to explore the potential for political mobilisation in the working class. In his influential Talking politics he analyses how participants, in the course of discussion, define themselves as 'we' against others. He puts this 'we' talk together with a sense of injustice, and a sense of agency, as the key elements of collective action frames.(Gamson 1992) Ten years later Cramer Walsh went further. In Talking about politics, she analysed the discussions that occur on regularly between acquaintances who meet in the mornings, in a corner store, drinking coffee and casually chatting. She argues that:

'... the fundamental politically relevant act is the communication of information about the kind of people individuals perceive themselves to be and the collective envisioning of group and community boundaries.' (Cramer Walsh 2004: 42).

Cramer Walsh suggests that political discussion is a matter of 'perspective', that is a point of view shared by participants; this point of view depends on social location, experience and identity.

'As with other topics, when people talk about political issues, they are relating to each other with the aid of social identities. Thus, they are neither interacting entirely as individuals nor as members of the community as a whole. Instead, through their interaction, they are collectively defining who constitute 'one of us'.'(Cramer Walsh, 2004: 52.)

Following Gamson and Cramer Walsh, we intended to examine the dynamics of politicization, but this time between unacquainted participants in a public setting. ${ }^{\text {ii }}$ We wanted to observe how participants would publicly discuss, agree and disagree about European issues. The time looked right, as European studies was emphasising the politicisation of European questions. In the French case our research design came shortly after the referendum campaign that was commonly taken to be an important 
moment of public controversy, and to evidence the fact that French citizens had become politically mobilised on the future of integration (Brouard and Tiberj 2006).

We designed the discussions in order to facilitate the expression of disagreement. Fear of conflict, and the reluctance to have one's opinion challenged by others, are major reasons for avoiding political talk in public. (Conover et al 2002). The dynamics of politicisation depend on participants taking the risk of publicly acknowledging disagreement with people they do not know, and whose opinions they do not know either. We suppose that people will take this kind of risk, and affirm views that might be challenged by others, only if the opinions at stake matter enough to them, or if they involve, explicitly or implicitly, some kind of commitment to people they like, who share their views, or are affected by them. Politicisation involves stances more than opinions, and cleavages that are the long term product of social and political structuring. So politicisation is involved with membership of social and political groups and classes, and it involves affect. Emotion and feeling, indeed, can be taken to be elements of motivation, the reason for participants' involvement in conflict or potential conflict. Instead of defining collectively who constitutes 'one of us', as did the participants in self-selecting groups of acquaintances studied by Gamson and Cramer Walsh, our participants could confront concurrent and conflicting accounts of who they are. These diverse and possibly antagonistic perspectives, of course, can generate anxiety and, sometimes, hostility. Analysis of our group discussions, thanks to the video recordings, is in this respect most interesting. Whether they speak, or remain silent, the body language of our participants tells the analyst a great deal about their emotions. It is observable when they are upset, or anxious; it is possible to see them wishing to react to what is said, but being unable to make their point verbally - in particular when they do not identify a potential ally in the group (Duchesne and Haegel 2006).

So the discussions we organized are particularly appropriate for examining identity issues related to European integration. Following and building on existing statistical analysis, we selected participants so that we could compare not only citizens from different countries, but also from different social backgrounds. We are able to compare how workers and unemployed people, employees, managers and 
activists, deal with emotion in the course of discussion with strangers. We can also examine whether their sense of self as national citizens, or as Europeans, is at stake when they discuss European issues. Our data seem thus particularly suited for addressing Fligstein's, and Hooghe and Marks's, theses on the identity dimension of working class euroscepticism and elite europhilia. Do our discussions confirm that working class people exhibit strong emotional attachment to their nation and its sovereignty, while executives display feelings of European membership?

More generally, does our research project improve our understanding of the European 'elitist bias'? Yes, indeed it does. However, this is not exactly as predicted by the literature. Our analysis does not suggest that less privileged people dislike the EU because they fear a loss of national sovereignty and the breakup of the welfare state. They do have these fears, but they are related more generally and profoundly to globalisation, not specifically - or in some cases, at all - to European integration. Regarding integration, what distinguishes workers - and, to a lesser extent, employees - from their managerial and activist counterparts, is their sheer lack of interest in Europe, the strong sense from the recordings that they simply do not pay attention to it, that they overlook it. European issues are not salient. This seems to be due to a lack of a sense of political agency, to the certainty that nothing can be done about it. Being in favour, or not, of the EU is just not an important question in these groups, not a question that can induce workers and employees to disagree with others on the subject. It certainly does matter, by contrast, to the managers and the activists, and they have emotional arguments about it.

We will try to demonstrate this in two ways. First, we analyse the answers the different groups of participants - workers, employees, managers and militants - gave to the third question we put to them in the focus group sessions: who profits from Europe? We present this analysis, showing the structure and content of arguments related to the distribution of EU benefits. This consolidates our findings on national differences presented in Chapter Two, as well as confirming the magnitude of social class differences. In this analysis, one group - a group of French managers - emerges as more eurosceptic than any of the others. A detailed analysis of their answers will challenge the idea that attachment to 
national sovereignty is a major component of opposition to Europe. Second, we broaden the scope of analysis and look at the dynamics of the whole discussion session for each group, examining the role that European issues play in these dynamics. We find wide variation, depending strongly on social class, and show that European issues are salient only for activists and managers. Third and finally, we discuss how this analysis challenges the thesis of growing identity conflict regarding European integration.

Before any of that we need to emphasise one specific feature of our group design. Because we wanted to analyse the (potential) politicisation of European issues, we chose to gather, in each group, participants with diverging views on European integration. To achieve this, we asked people who applied to participate in the discussions two questions about the EU adapted from Eurobarometer. (Appendix 2) We aimed to include in each group both individuals who said they were and were not in favour of integration. So our research design does not allow us to compare the rate of pro- and antiEU arguments for the different social class groups. We cannot judge or refute the recurring observation that working class people are on average less europhile than elites. In fact, we found support for this hypothesis at our recruitment stage, when it was sometimes difficult to find working class applicants, and not difficult to find managers, who declared themselves in favour of the EU. Our comparison, at any rate, focusses on the nature of interactions in the different class groups, seeking to analyse what they can tell us about the relative salience of European issues for them.

Who profits from Europe?

This question was the third one in the group session schedule, and the first of the second half of the session, just after the break (Appendix 4). Participants were asked to group together in twos or threes. We gave them cards and markers, and asked them to form about six answers to the question 'Who profits from Europe?' They weren't aware of the question before they began work on it. Preparing the answers took about ten minutes on average. Then the moderator collected the cards, shuffled them and posted them on the board, one by one. Participants commented on each card as it was posted, and 
these comments in turn, were written and displayed using cards of a different colour (Appendix 6 for an example of what a board, at the end of this part of the session, looks like). Most of the time, participants identified who were - or even who, within the sub-group, was - the author(s) of each card and elaborated a bit about the point they tried to make. The rules, otherwise, were the same as for the rest of the discussion: any comment was recorded and written up, and a 'flash' was indicated on demand, if a card or a comment was subject to question or disagreement. Flashes were discussed once all the cards were up.

This series of answers seems thus particularly meaningful: they are not 'top-of-the-head' replies quickly provided by people in isolation. Each of them was elaborated and negotiated by (at least) two participants who had, beforehand, discussed the topic for about an hour and a half. We moderated the sessions in such a way that participants were free to turn the conversation to the subjects they found most interesting - obviously this carried the risk of them discussing anything but European issues. In this context, these answers and this particular passage of discussion, are clearly the more focussed on the research topic. So, although they are not the liveliest parts of our sessions, this question is certainly the one which allows us the more easily to keep to the European studies debate. We can provide indepth analysis of who Brussels, Oxford and Paris citizens consider to be the winners of integration. It might seem paradoxical to look for identity from discussion of interest, but this is what the Euro-clash thesis is about.

The question generated 353 answers distributed between the 24 focus groups, with about 330 cards written in total. Participants were asked to write one idea per card but did not always follow the rule. We here analyse the whole set of cards produced by all 24 groups - both our sets 1 and 2 - in order to achieve a number of answers sufficient for statistical analysis. 
Table 3.1: Frequency of answers to the "Who profits" question, by group.

\begin{tabular}{lccccccc}
\hline & \multicolumn{2}{c}{ Brussels } & \multicolumn{3}{c}{ Oxford } & \multicolumn{3}{c}{ Paris } \\
& Set 1 & Set 2 & Set 1 & Set 2 & Set 1 & Set 2 & Total \\
\hline Managers & 15 & 16 & 10 & 18 & 14 & 22 & 95 \\
Employees & 10 & 11 & 23 & 11 & 14 & 17 & 86 \\
Workers & 15 & 9 & 6 & 9 & 18 & 19 & 76 \\
Activists & 13 & 12 & 17 & 21 & 19 & 14 & 96 \\
\hline Total & 101 & & 115 & & 137 & 353 \\
\hline
\end{tabular}

The number of answers per group varies according to city and social category: activists and managers tend to give more answers than employees and workers, which is not unexpected. However, the Oxford groups are more prolific than Brussels ones, and this does not reflect the general length and animation of the discussions. As for the Paris groups, the level of prolixity on the cards reflects the generally high levels of prolixity in the discussions. However, these city differences are by no means exact: in Oxford the distribution of number of answers ranges from 6 (Oxford set 1 workers) to 23 (Oxford set 1 employees). The length and precision of what is written on the cards also varies quite a lot.

Europe profits the economy

Responses are quite diverse, as table 3.2 suggests, although the coding was relatively straightforward, with the exception of some jokes, and some obscure answers. The answers we got do not look like a series of clichés. 
Table 3.2: Frequencies of coded responses to "Who profits", answers, and queries and challenges (flashes)

$\begin{array}{llll}\text { Code } & \mathrm{N} & \text { Examples } & \text { Flash }\end{array}$

LIB 37 Capitalism, liberalism, big companies, world companies, Disney, L'Oreal, 5 the world market

CIT 34 Us, to the citizens, the Europeans, those who are inside, equality between $\quad 20$ Europeans, consumers, workers, any word that would refer to the participants.

ECO 31 The economy, business, enterprises, retailers 4

$\begin{array}{lll}\text { MOB } & 29 & \text { Travels, mobility, translators, students and Erasmus programme }\end{array}$

$\begin{array}{llll}\text { VAL } & 26 & \text { Rights, environment, associations, peace, culture, or other values } & 7\end{array}$

$\begin{array}{llll}\text { POL } & 24 & \text { Politicians, MP's } & 4\end{array}$

PAUV 20 Poor countries, inside or outside the EU 5

NEG 18 Any explicit negative answer as unemployment or vicious circle, including 7 not us, not me, not the farmers, or sceptical answers (profit???)

TECH 18 Experts, technocrats, Commission people 1

NOUV 17 Eastern countries, new EU countries, former new countries 2

XXX 14 Other: very varied. May be a joke, or a topic that was quoted once only (ex. 0 Eurovision, media)

BANK 13 Banks, bankers, finance, money 2

$\begin{array}{llll}\text { EXT } 12 \text { Countries outside the EU, the world } & 6\end{array}$

AGRI 11 Agriculture, farmers 2

$\begin{array}{llll}\text { IMM } & 8 & \text { Immigration, to foreigners } & 4\end{array}$

$\begin{array}{llll}\text { RICH } & 8 & \text { Rich countries, the rich } & 3\end{array}$

USA $\quad 8 \quad$ United States, the Anglo-Saxon world 4

$\begin{array}{lll}\text { CRIM } 7 \text { Mafia, crime, terrorism } & 2\end{array}$

$\begin{array}{llll}\text { RECH } & 7 & \text { Research or researchers } & 0\end{array}$ 
PAY 5 Each time a specific country name is given, except the US 0

$\begin{array}{lll}\text { DEF } & 3 & \text { Defence, the military }\end{array}$

$\begin{array}{llll}\text { BXL } 2 \text { Brussels, Brussels' inhabitants } & 0\end{array}$

The response that 'Brussels' profits (BXL) - a typical cliché in public political discourses - is quite rare. Putting that answer together with TECH, which codes answers referring to the people who work for the EU, technocrats, commission members and bureaucrats, including lawyers and translators, we have about $6 \%$ of the total - important, as expected, but not paramount. Farmers and agriculture (AGRI) are also mentioned, but are not central in the discussions.

Three major categories sum up the positive influence of European integration. About 10 percent of the answers refer to the participants themselves - citizens, Europeans, consumers, workers (CIT): 'It profits us' say Set 1 Brussels employees; 'in principle to anyone' reply set 2 Paris employees; 'people' add Set 2 Oxford workers. The idea that the EU profits all of us is complemented by numerous references to values (VAL) like peace, culture, rights, environment, exchanges and diversity. More concretely, Europe benefits mobility (MOB), in particular for students, through the Erasmus programme, and tourists, and thus profits the travel industry, as well as workers. But immigration is also mentioned as such in a third of the groups with simple words like immigration, immigrants, emigrants or foreigners (IMM). We saw in Chapter Two that boundaries are central in these discussions. These cards confirm it as these two categories - MOB and IMM - are complemented by two others that put the EU in the picture of the global world. Code EXT gathers 12 cards that refer to the external world, like 'all countries' (Set 2 Oxford workers), 'extra Europeans $=$ the first cooperating' (Set 2 Brussels activists) including clear references to post colonialism: 'it profits the non European world, Africa, former colonies' (Set 1 Brussels employees). Moreover, the US and the anglophone world (USA) are mentioned as a beneficiary of integration by a third of the groups. 
Another support for the analysis of Chapter Two is the number of references to the economy. Cards which suggest that Europe profits the economy were so numerous that we split them in two categories. The first (ECO) gathers references to economic actors, for instance: 'that profits the economy' (Set 1 Brussels, managers), ‘import/export. Profit for European economy’ (Set 2 Paris, workers) or 'organisations, businesses: companies within the EU trade' (Set 1 Oxford, employees). The other category (LIB) puts together answers that imply a power or size element such as 'big business', the world market, and answers related to economic liberalism and capitalism in general that imply winners and losers. For instance: 'to foreign industrial investments with lower costs, tax advantages' (Set 1 Paris employees), 'cheap labour' (Set 1 Oxford managers), 'political class that represents the interest of multinationals' (Set 2 Brussels activists). Banks and bankers (BANK) are kept apart. These three categories together represent more than one in five of the answers.

A final important category is constituted by numerous references made to politicians (POL). Be they M(E)P's, political leaders, heads of state, these people are overwhelmingly considered beneficiaries of the integration process: only five groups out of 24 (Set 1 Brussels managers, Set 1 Paris managers, Set 2 Brussels workers, Set 1 Oxford activists, Set 2 Paris activists) do not mention them on a card.

For anyone familiar with the discussions in these groups, it is striking that the tone of these cards is generally neutral or even positive. Cards that can be coded negative $(\mathrm{NEG}=18)$ are rather rare. Cards referring to crime, the mafia and so on, are even rarer $(\mathrm{CRIM}=7)$. By contrast the general tone of the sessions overall was much less positive and more sceptical. This may first be considered a consequence of the question itself, which already includes a negative nuance. Indeed, participants sometimes asked, orally or by writing it on the cards, whether the question should not have been 'who benefits from Europe?' We had included the provocation in the question deliberately; it looks as though the result might have been to induce participants to moderate their answers. However, these cards were submitted, like the rest of the discussion, to the 'flash' rule whereby participants let the moderator know if they had any question for or challenge against any card. These cards, which we should remember were written directly by the participants rather than scribed by the moderators, were 
flashed quite often: 63 times, that means almost one in five. The flash rule, which was meant to make the expression of disagreement almost attractive, was used by our participants here to balance or challenge the positive view of integration. As Graph 3.1 shows, codes that correspond to the more positive answers, citizens and values, are the ones which were 'flashed' more often. The most negatives answers - crime, mafia, and the negative category - were also contested, but not as much.

Graph 3.1: Percentage of flashed cards by code.

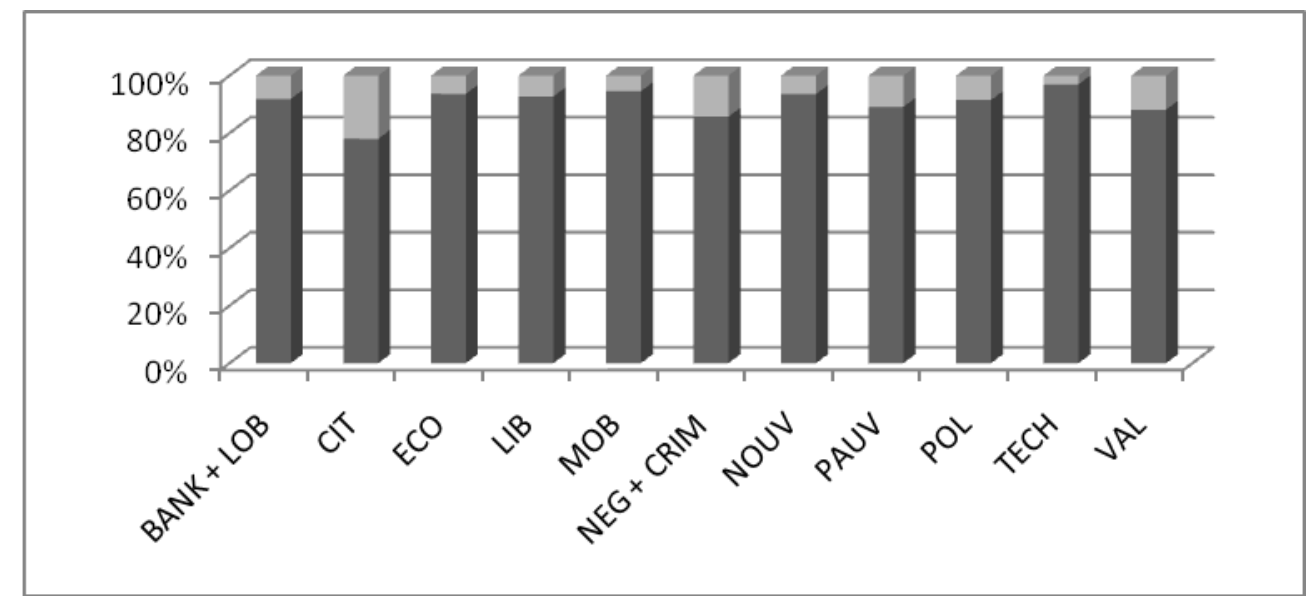

How are these different conceptions of winners and losers of integration distributed among categories of groups? In order to get a overview of how our participants understand the consequences of European integration, as evidenced by these responses, and to get an idea of how these understandings relate to social class, we proceeded to a principal component analysis of the codes distribution. ${ }^{\text {iii }}$ 
Graph 3.2: Principal components analysis of coded responses to "who profits from Europe?"

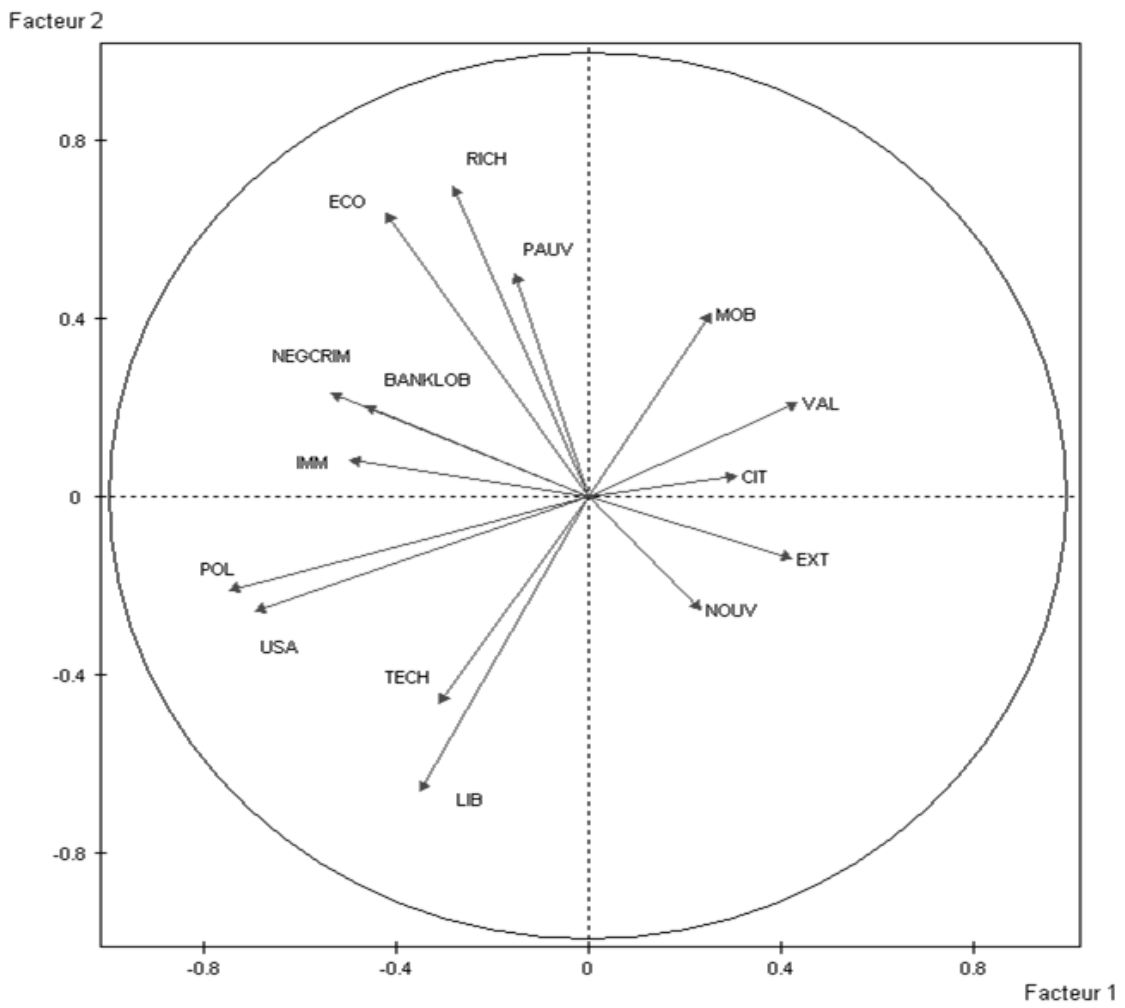

In this analysis, two factors together explain $35 \%$ of the variance. The first factor (horizontal axis on the graph, about 20\%) could be called 'Profit or Benefit' as it reflects the ambiguity of the question wording, where profit could be interpreted as serving material interests, presumably of some people more than others, or alternatively as benefiting people in general and in principle. The factor opposes the benefits of value, mobility, equality and openness at one end to profit for politicians, the US, and the economy in general, at the other. Analysis of the distribution of flashes between groups confirms that the former conception of profit - profit as benefit and value - is more contested and debated than the latter conception - material profit taken by particular groups. The themes of values and citizens' benefit, are associated with an emphasis on openness - Europe profits its new members, but also the rest of the world. Cards coded NOUV have no negative denotations or connotations, even if they often link being a new member with being a poorer member. A card written by the Set 2 Oxford managers clearly states this: 'poor countries, benefit not profit'. 
The second factor (about 15\%, vertical axis on the graph) is structured by the opposition between general references to the economy and references to big business. We could call it 'Capitalism or Market'. Participants are ambivalent in their understanding of the economy. Economic exchanges are both beneficial (to poor countries and poor people as well as rich ones) and damaging (growth goes together with the increase of crime for instance). Immigration - and this comes out clearly in the discussions - embodies this ambivalence. It is beneficial for the people who migrate as they get a chance to avoid poverty; however this costs them a hard life as migration means leaving behind you people, places, habits you like and you are not likely to be welcome in the host country. Moreover, it damages the life of people in host countries because of the pressure on the labour market and the resulting low wages. Mobility contributes to this, in particular because of the tourist industry. Opposed to this is an understanding of the economy driven by big businesses, by multinationals, by capitalism. References to the US also contribute to this. What is interesting is that the technocrats - EU people in particular - and to a lesser extent, politicians in general, are closely related to this latter understanding of the economy.

The picture that emerges from this analysis thus also confirms what we saw in Chapter Two. The positive evaluation of European integration, based on values, mobility and citizens' advantages, is challenged by the negatively evaluated power of economic processes and flows which seem to dominate. Moreover, integration does not happen in a vacuum: participants are strongly aware of the global world, and the benefits of integration cannot be dissociated from what is happening, in particular, to emerging countries and to former colonies. Lastly, and we will return to this, euroscepticism seems less to be related to the loss of national sovereignty through the integration of political institutions and public policies, than to the belief in the irresistible power of capitalist economy. 
Low working class levels of europhilia

According to recent work in European studies, working class people are expected to be more eurosceptic than other groups. We have seen that the way we designed the groups, each including both pro- and anti-integration participants, should have neutralised any such effect in our sample. However, the different social class groups are still distributed unevenly in respect to the expressed understandings of the benefits and burdens of European integration. We can see this clearly by locating our class groups in the space structured by the two factors.

Graph 3.3: Principal component analysis of 'who profits' responses: location of national and social class groups in relation to factors 1 Profit or Benefit and 2 Capitalism or Market

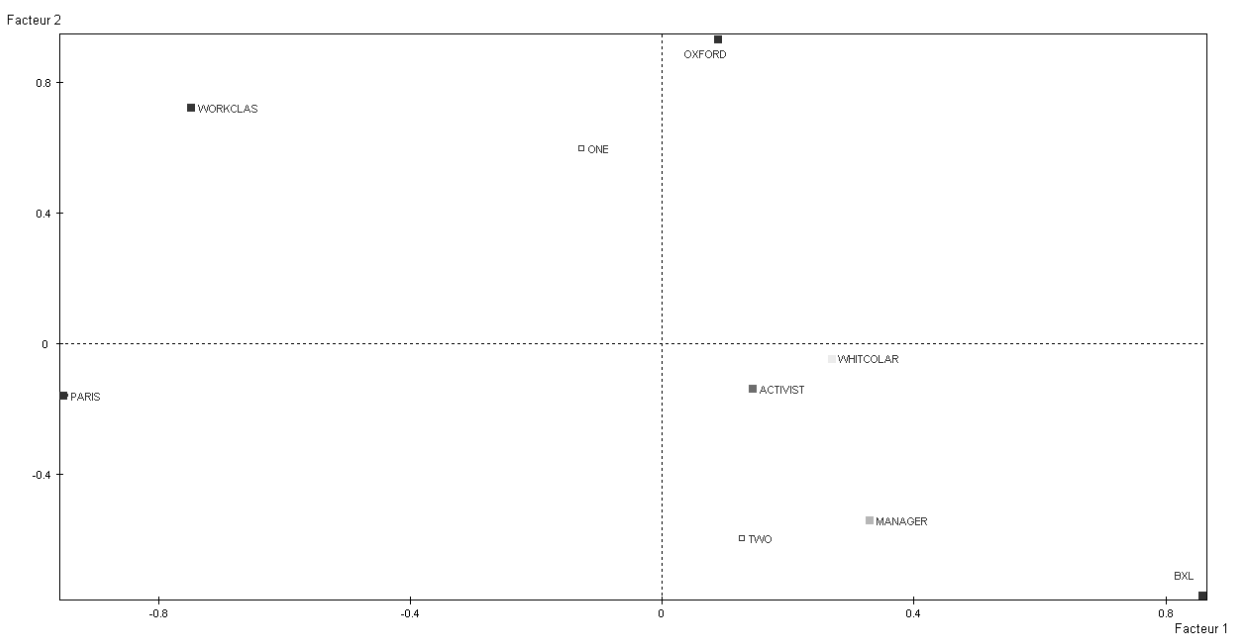

This graph first supports our finding in Chapter Two of strong national differentiation. European integration is framed differently in the three cities. Parisian and French speaking Belgian groups are clearly opposed to each other on the 'Profit or Benefit' factor. Brussels participants refer more often than others to European values and citizens as beneficiaries of integration - even if this was frequently contested. Parisian groups, by contrast, consider the EU as mainly oriented towards or by the economy. Regarding the 'Capitalism or Market' factor, the Brussels and Oxford groups are opposed. When referring to the economy, Oxford participants are more inclined to refer to the free market that, with its own dynamic, brings Europeans growth and crime at the same time, and might advantage the 
poor as well as the rich. Brussels responses relate more often to globalized capitalism, which benefits big business more than others. National frames are clearly prevalent here. This reminds us that, as Cautrès and Grunberg put it, if social differences of opinion regarding European integration remain strong in all countries, the social bias operates within the countries (Cautrès and Brunberg 2007). In this way national differences are first and social differences second.

However, this graph also shows a clear differentiation between working class groups and others. Workers' representations of the consequences of EU integration are more embedded in an understanding of economics that does not give much consideration to any European achievements concerning mobility, citizenship or values. But their understanding of the economic influence of the EU is not particularly negative or cynical, by contrast to the managers. Employees, like the activists, are located between working class groups and managers on the two dimensions, 'Profit or Benefit' as well as 'Capitalism or Market'. This result suggests that our respondents' understandings of the benefits and burdens of EU integration are not exceptional, given what we know about distributions of opinions in the population. But we must not over interpret this picture of national and social differences. Within each group, positions on each factor are contested; and a more detailed analysis of the position of each individual group in relation to these factors shows that there is less organisation than the foregoing analysis might suggest. 
Graph 3.4: Principal component analysis of the 'Who profits' responses: location of individual socialnational groups in relation to factors 1 Profit or Benefit and 2 Capitalism or Market

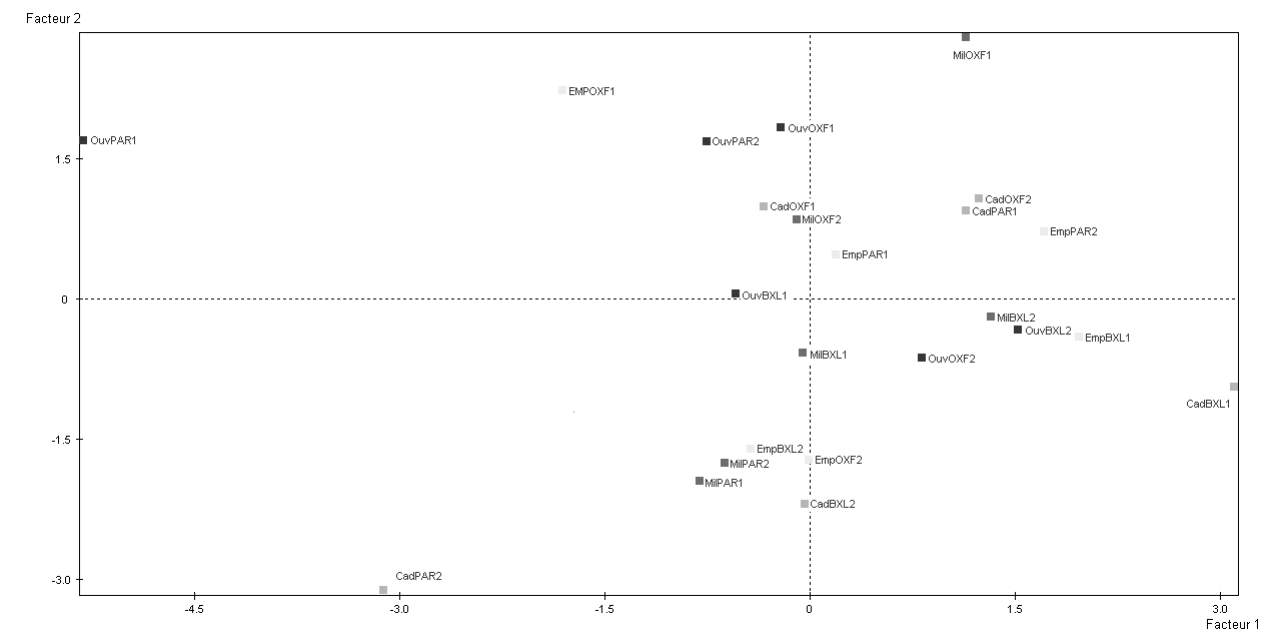

From this analysis we can also see that the positions of some of the individual groups have a strong influence on this whole structure of national and social differences in understandings. Notably two Parisian groups - the Set 1 workers, and the Set 2 managers - make a strong contribution to the national differences on the first, Profit or Benefit, axis. They are far less sensitive to any EU benefits. Later in this chapter, we compare the way the groups we gathered into Set 1 react in the context of the whole discussion of Europe. Next, we examine more closely the Set 2 Paris managers. This is the group that contributes the most on the 'capitalism' end of Factor 2. It emphasizes the role of Brussels bureaucrats, of the US, and of big business in Europe. We might expect this group to provide us with a good example of euroscepticism. We want to examine whether and how national identification plays a role in this.

The limits of sovereignty

The Set 2 Paris managers gathered together six middle-aged men, with jobs such as professor, lawyer, IT manager. On paper, they seemed to be politically very heterogeneous and hence a potentially conflictive group. Participants' past votes ranged from Besancenot - extreme left - to National Front. Their attitudes toward the EU were similarly heterogeneous: three declared they had voted in favour of 
the Treaty, two against, and one had not voted in the referendum that had taken place about six months earlier. We know from the questionnaires that one of the group was of North African descent. However, they had the appearance of six white men and they behaved like a bunch of tipsy old friends.

First, they reacted against the two moderators (both women) quite strongly, calling them 'mademoiselle', and making sexual jokes which became heavier and heavier as the discussion proceeded. ${ }^{\text {iv }}$ At the end of the second section, when they were asked to put stickers up on the board and choose between the four suggested sources of power in Europe - the market, the nations, MPs and experts - one said it would have been funnier using darts. The moderator didn't know whether to interpret this as a provocation, given that she was in the line of fire, as it were. Second, they refused to obey the rules of the discussion. They kept chatting, shouting short sentences without explanation, making endless allusions that made it difficult for the moderators to catch their meaning and transcribe it, dropping names, and laughing out loud. They became even more animated once the discussion turned to the entry of Turkey into the EU. They lost control and jokes, on top of being sexist, became overtly racist. All of this explains why we have left this group out of the main analysis, putting it into Set 2 with others that are less comparable. Other groups were either ethnically or gender mixed, or both, and this clearly influenced the way participants exchanged views and perspectives regarding their identities. In addition, this group discussion was technically almost impossible to transcribe, as they were so often chatting together and shouting at the same time.

This is a pity, as this group is indeed the most 'sovereigntist'- the term used in French public political discourse - of them all. Although three participants declared beforehand they had voted in favour of the Constitutional Treaty, the tone of the discussion is at first sight clearly hostile to Europe. This hostility explicitly emphasises a particular French perspective. They comment at length on the corruption of European elites, note that the French central bank does not have a word to say any more, complain that nobody cares if a majority of French voters rejected the Treaty, and suspect that more and more European countries are happy to go on without taking any notice of the opinion of the French. They recall how De Gaulle used to call the United Nation 'le grand machin' (the big what's- 
its-name). They suggest that 'Europe' - they are like most of the French participants in referring to the EU this way - is just a 'big and distant ectoplasm', a 'chaos'.

The 'who profits from Europe?' exchange is no exception in this group discussion; it is as chaotic as the rest of it. Four participants lead the game, hardly paying attention to the moderator who puts up the cards on the board and solicits comments, but mainly gets jokes in return. They either make fun of French politicians or, when going back to the discussion, they challenge each other about the cards that they have written, mimicking school children and even dunces. One of the participants, Patrick, a civil servant who voted extreme left, and in favour of the Constitutional Treaty, hardly speaks. For the 'who profits' exercise he was partnered with Michel, a Chirac voter who declared a no vote in the referendum. At one point he tries to intervene in the talk to explain why they wrote 'older members' as well as 'new entering countries'”, the others object that Patrick and Michel are 'changing sides'. They insinuate, as a joke but in a pretty offensive way, that Patrick has been illegally paid by CNRS or is a friend of the moderator. Patrick insists; he says he wants to justify the card and evokes Renault's subsidiary company in Romania, Dacia, and financial profits for firms in older countries. He is strongly rebuffed by François, ICT manager, who makes them all laugh (apart from Patrick) at the idea that French Renault workers will be fired in Alsace but offered a job in Romania instead, with a $110 €$ monthly salary - 'or in Mauritius' he adds. François, a Chirac voter, is one of the leaders in the group. Although he declared he voted yes at the referendum, he constantly opposes any positive appreciation of EU benefits and finds support for this from the others, quite independently of whether they voted against or in favour of the Treaty. François, together with Louis, leads the game against the moderators, who represent Sciences Po and CNRS, both suspected of supporting integration.

Outsourcing in Eastern European countries as well as Eastern immigration into Western Europe are recurring topics in this as well as in other groups. When Patrick suggests that it is a good thing that entering countries gain social benefits 'after all', Louis acknowledges that integration indeed boosts smaller countries but adds 'on the opposite side, for the French, the average French guy, it's not obvious'. However, the difficulties for the 'average French guy' are more generally speaking 
considered a consequence of outsourcing and immigration. In the sequence described above, François seems to consider that French workers being transferred to Romania or to Mauritius would be exactly the same (only that in Mauritius, at least they would get the sun). What stands out from this group's discussion of the 'who profits' cards is not that the French are specifically affected by European integration; if or when they are, it is explicitly said that this is the same for other big and old members of the EU. In contrast with Jonathan White's findings (White 2011), French participants do sometimes mention the Germans, in relation to enlargement at least, as almost fellow citizens who experience the same kind of problems as they. Rather, what stands out is the role that politicians play in the game. Politicians (French politicians) are unanimously considered beneficiaries of Europe. The third card put up on the board in this group 'M(e)P's'(les élus) ${ }^{\mathrm{vi}}$, is the first which gains attention. It generates fierce comment: 'Yes, of course, MP's. And their court' replies François. Louis adds that together with experts, MP's form a nomenklatura, and they all laugh and agree. They take great pleasure in denigrating French political leaders. François and Louis, again, compete with absurd details about prominent French politicians. Moreover, there is no distinction between European and national leaders: European positions are considered consolation prizes taken by national leaders when their career becomes less successful. Valery Giscard d'Estaing is thus target of mockery for his involvement in the European convention which is compared to his desire to get elected to the French Academy. 'Looking a fool does not kill anymore' concludes Louis.

Clearly, European governance is not understood by this group of managers as an autonomous level of decision, which might get in the way of the French government's ambitions and will. If the average French citizen suffers from the EU, it is not because French plans are thwarted by other European members. It is first and foremost because politicians, French politicians, do not fight for or even try to represent French people's interests, be it in Brussels or in Paris. Earlier, when discussing how we should distribute the power in Europe, Michel notes that a fifth power is missing, the citizens. Stanislas suggests that they are represented by MP's but the others contest this; Jean-Paul asks if they are not with the market. They briefly agree that the citizens are everywhere, but that they don't know 
where they should best be located; they call them 'the fifth element'. Most strikingly, nobody in this group suggests that citizens, the people, might be included in the nations.

This kind of confusion between national and European political leaders, and a consequent absence of any vision of European governance as such, might seem specific to the French situation. In France, opposing Europe is mainly a non-governing party attitude, from the far right and the left. Within governing parties, until recently, leaders who tried to develop eurosceptic arguments had to leave or give up. (Rozenberg 2007) So in public discourse, the rejection of Europe tends to go hand in hand with a denunciation of the legitimacy of governing leaders, of their lack of consideration for the people. But as we will see below, such relative invisibility of the European power, linked to a complete distrust of national politicians, is not confined to our French participants. What is specific to the discussion presented here is that it is produced by a group of managers. In Brussels and Oxford, this kind of representation (albeit without the hysteria) instead is characteristic of working class, and to a lesser extent, employees, groups.

It is also clear that this group's euroscepticism is not based on exclusive nationalism in the sense that Europe is rejected because it limits national sovereignty. They might doubt that 'the French average guy' profits from Europe. However, the nation as a whole, as a community, as a source of solidarity, of power is notably absent from this discussion. This absence is all the more striking for the fact that the topic of national power had been explicitly raised in the question 'how should power be distributed?' half an hour previously. It is also absent from the whole series of cards produced by the 24 groups. The few mentions of 'us' that we encounter in these answers refer to the citizens, the Europeans themselves as participants (or as young people by the Set 1 Brussels employees) but never 'us' as the French, the Belgians or the British. Our detailed analysis of this series of answers has been intended to provide some kind of objectivisation of the unexpected relationship that our participants maintain with the EU. In order to explore this relationship more deeply and to delve further into the question of social differences, we now return to an interpretive analysis of the general dynamics of the Set 1 groups' discussions. 
The double meaning of overlooking

The discussion schedule was elaborated so as to favour the development of conflict on Europe in the course of the session. Things did not go exactly as planned. Although conflictualisation occurred, not all the categories of groups engaged in any conflict on European issues. This is where the social gap is significant. The two questions in the first half of the session were designed to allow participants to take the measure of each other's opinions, and to give us an idea of participants' degree of knowledge and comprehension of the integration process. Then came the break, with the provision of food and drink, which favoured sociability and a degree of conviviality. At the return, we planned to divide the participants into sub-groups of two or three, and ask them to work together on responses to our provocative question 'who profits from Europe?' Our intention was to get participants with some similarity of opinion and attitude on European questions to work together. The idea was to maximise differences between sub-groups so that when the whole group came together to discuss the written responses, the differences would have to be confronted.

In the event, our scheme did not work. At least, it did not in the working class, nor the employees, groups. Far from being a moment of escalating conflict, the response to 'who profits?', although interesting, was actually the least lively part of the discussion. First, it proved almost impossible, notably with the working class and employees' groups, to detect from the first half of the discussion individuals who matched, or paired, in respect of their attitudes to Europe. After an hour and a half of discussion on the subject, we found it more or less impossible to distinguish the opinions of one participant regarding European integration from another, or at least to say with any clarity who was for and who against the EU. To be sure, we had the pre-collected responses from the two questionnaires. But the responses given there proved to be singularly poor predictors of the positions taken or not taken in the discussion. This is by contrast with other issues, where responses given to the questionnaires, and positions taken in the discussion, clearly matched. (Haegel and Garcia 2011) It was difficult to know what to do. If we asked participants to choose with whom they would work after 
the break, they felt uncomfortable about this, and tended to 'choose' the person they were speaking to when we asked them to choose a partner; or they simply returned to the seating order from the first session, and worked with their neighbour(s). Sometimes we made pairs on the basis either of the questionnaires or of the moderator's evaluation of participants' opinions. But in this case, as in the others, we ended up with sub-groups that never particularly mapped on to any kind of disagreement on Europe. Further, the responses produced on the cards by the sub-groups of participants, even when they seemed to voice contradictory opinions regarding who were the beneficiaries of European integration, didn't really drum up any animated discussion when they were put up on the board.

Nevertheless, our system was well able to generate conflict. The question on entry of Turkey into the EU, which was preceded by an individual vote (with the aid of a sticker which was put on the board), generated passionate discussions in all categories of groups. These, though, were fuelled mainly by contradictory opinions about Turkish culture and democracy, about religion and xenophobia, not to mention geostrategic questions and political economy. Only a very limited number of opinions expressed with any intensity bore on the consequences of Turkish entry for the future of the European Union. How far can enlargement get - in the sense of: how many countries might enter the EU without putting it at risk, as a political system - was never an issue. It might be mentioned, but was not debated.

This does not mean that these groups were a failure, generally speaking, regarding conflictualisation. We did get quite a lot of emotion and openly expressed disagreements; but rarely on Europe. Our nondirective moderation technique did allow participants to engage in conflict, but on issues that were important to them. These included immigration and people's welfare - how many incomers can a society absorb? how can we calculate the relative cost of immigration for those who come and those who receive? how incompatible can cultures be? How much are Europeans as former colonialists responsible for poverty in ex-colonies, and hence for migration? Individual responsibility and state intervention was a similarly lively theme - is unemployment related to parents' education? who is responsible for incivility, petty crime and long term benefit claims? what can governments do in a 
globalized economy? who suffers the most in today's society? These debates support public opinion research findings regarding the main cleavages in Europe. They also support White's results: what matters to people, on top of the economy, are issues related to 'society and the law' and 'relations between people' (White 2011). But questions that are supposed to be at the core of eurosceptic positions and fuelled by attachment to national sovereignty - like 'do we need more or less European power? do we want European federalism or a supra-national state? how far can the EU go in imposing legislation in the member states? who are these European leaders who prevent our national elected politicians from governing our country according to our wishes?' - these questions never generated strong feelings and conflict in our groups. There are some very brief exceptions in some managers groups; and the more important exception of our activists.

In order to demonstrate the relationship between salience of European issues and group category, we will go briefly through each. We begin with the groups who played their parts more or less to the script - the activists. In all three cities, European integration and the current state of the EU was the main topic of discussion between the activists, for the full three hours of the session. The pro- and anti-EU stances evident in these discussions, were based on high levels of knowledge of the issues, but also reveal the significance of other identifications and cleavages. Within the British Set 1 activists group, disagreement on European integration is deeply rooted in fundamental disagreements about social justice and market regulation. One of two Conservative participants, James, is opposed in his vehement euroscepticism to a Liberal-Democrat European Parliamentary candidate who accordingly voices a strongly europhile position. Two Labour activists, one of whom, Bethany, is an elderly and respected local councillor, and the Green party member, although they are far from enthusiastic about the EU, clearly take the side of the Lib-Dem in opposition to the assertive and aggressive stances against any kind of economic or social regulation taken by James. For him, the EU mainly is a limitation to the free-market and employers' rights. His complete rejection of any kind of social consideration turned the others against him, although the other Conservative participant backed him up to a limited extent. Bethany, in particular, invoked with emotion the suffering that working people went through before the institution of the welfare state. The dynamic of the discussion was such that, 
as they oppose James and his virulent euroscepticism, the majority of the participants find themselves supporting the EU more or less willingly and explicitly.

Among the Belgian activists, the conflict on European integration also developed through the session, and remained quite central up to the moment when the question on Turkey's entry into the EU changed the tone of the debate. During the break, the participants discovered their respective political affiliations and they addressed the 'who profits?' question, quite cheerfully, as political opponents for whom Europe affords a pretext for confronting arguments and positions rather than as a profound reason for opposing each other. But with the question on Turkey, the playful disagreement turned into a fundamental conflict where identity came into play. The cleavage between Judaeo-Christian legacy on one side, and secularism and tolerance for diversity on the other, reveals a profound antagonism between the Ecolo participant, whose North African origin was not noticeable ${ }^{\text {vii }}$, supported by the Parti Socialist participant, and the two rightist parliamentary attachés. The other two participants, although also activists, are less professionalised than these four, and for the most part are listeners. At the point where the discussion of the compatibility between Turkish society and the values and habits of European societies engages the participants' emotions and self identifications, the discussion sometimes almost got out of hand. The opposition between the pro EU attitudes of the pro-entry participants and the more sceptical attitude of the two Mouvement Réformateur and Centre Democrat Humaniste activists gained an unexpected strength in this discursive context.

The discussion of the French activists was particularly animated, partly because two of them - the Green representative, who happens to belong to an older generation than the other five participants, and one of the two Union pour un Mouvement Populaire members - talked too much and irritated the others. Moreover, the referendum campaign had happened only a couple of months previously, and all the arguments were still fresh. At some points, they even acknowledged that they were replaying the campaign and the only female participant, one of the two Socialists members, expressed her lassitude. However, they strongly opposed each other about the role of the EU. Regarding globalisation - is it a Trojan horse or a protection for Europeans? Enlargement - does it empower or weaken European 
integration? Above all, they argued about Turkey's entry. Their debates were not only livened up by well rehearsed arguments, they were also fuelled by personal disclosures.

Being pro- or anti-EU also means something to the managers, but their positions in this respect are not always sufficient to animate their discussions. In Oxford, one shop manager, Sundai, stands alone against the others. He is Black, strongly expresses his feeling as British, but argues at length that Britain has to be more European, and that the EU is good for the economy as it facilitates goods' and people's mobility. He challenges the others, and one by one they join in a confrontation with him. The discussion remains thus centred on this conflict to the end. The others, by the way, find it difficult to believe in Sundai's europhilia. At the end, after he had left, one of them asked whether he was a plant in a covert experiment. The Belgian managers were very knowledgeable regarding the EU and their discussion ran smoothly. Valerie, general practitioner, was slightly more engaged than the others and defended a more optimistic vision of the EU. But they generally agree on a positive assessment of the European project, and a more critical evaluation of the current state of the EU. The real conflict occurs at the end of the discussion and leaves Europe aside as Valerie, backed up by the other female participant - both are practicing Catholic - confronts Roger's strong atheism. The French managers also exchange knowledge about European integration, but it is not as accurate as the Belgians' understanding, and the discussion is more chaotic. This is all the more as it becomes more and more influenced by a growing antagonism between a young communist doctoral student, Fabienne, and an engineer in his fifties. Fabienne's explicit euroscepticism is only one among many other arguments in their long-lasting conflict, but it contributes to keeping Europe at the core of the discussion.

In the three cities, then, activists and to a lesser extent managers discuss European integration on the basis of their more or less positive appreciation of it. For the managers, though, real conflicts, when they occur, are only partly related to European positions. The activists, by contrast, deploy strong arguments that strictly relate to the speed and nature of European integration. Europe is what they agree and disagree about. This is far less the case in the employees' groups. 
In the British employees group, the discussion never really began until the question on Turkey's entry was posed. Then the conflict between Mike, white middle aged office manager, and Kamal, young Asian Muslim catering team leader, did not refer to Europe at all, but to Islam and Islamophobia. Before that point, Mike had led the discussion. His knowledge about political economy and institutions generally speaking, and regarding Europe in particular, exceeds the others' very much, and this makes it difficult for them all. This is one of the groups where sovereignty and euroscepticism is addressed quite a lot, especially by women, by a middle aged receptionist in particular. But this is not in vehement terms. This might be because they all fear disagreement, although Mike and Kamal's conflict about Turkey shows that they can overcome this when they feel strongly about an issue. Nina (care worker in her thirties) made a final comment regarding the fact that she had talked about Europe in this discussion more than she ever wished to, illustrating how strength of feeling could not be generated by the EU.

The French employees kept sidetracking. The discussion of the question 'How should we distribute the power in Europe?' shows how little they know about the EU. It seems that they did not even know about the direct election of MEP's. The two important conflicts occur about the welfare state and Islam. Hadia, who was looking for a job in advertising, tried several time to go back to the topic, Europe - she calls it the 'CEE' (EEC) - but eventually reaches the conclusion that what matters is not that France belongs to Europe but the fact that it's a rich country. By contrast, the Belgian employees were capable of carrying on talk about Europe during the three hours of discussion. They first hit a quite positive note, looking clearly pro-European and indeed, we did not manage to invite a declared Eurosceptic participant to join this group. But as the discussion proceeded, the overall positive appreciation weakened. Their reservation increased with the 'Who profits from Europe?' question. They clearly indicate that what they said was what they had been told to believe. In reality they consider the current price for the EU is high, that they are paying, and they doubt they will ever experience the benefit of it. Although they are all quite young, they mention future generations who will have become Europeans because they would have been made so - they use the metaphor of a computer chip that will have been implanted into younger people. In different ways, the Oxford, Paris 
and Brussels employees all maintain a kind of distance from Europe and the EU. This distance does not prevent them discussing it, or trying to in the case of the British and French groups, but it cannot generate strong disagreement. The image of the computer chip, used by the Belgians, evidences a striking sort of detachment. They feel that becoming European is something that is going to happen because it is what has been planned. They expect it will not be painful; although the cost that they are bearing in the preparations for the transformation is.

By contrast, pain, resentment and even despair sometimes resonates through the working class discussions. The British are certainly the group which resembles most the euro-clash picture of working class attitudes. The group gathers together five participants, although three of them are leaders in the conversation. Robert, bricklayer and ex-military, is the more knowledgeable. He suggests recurrently in a quite articulate way that Britain should join the Euro. Brenda, a post office worker, does a lot of group work. She prompts others to participate, to keep the conversation going, but also has strong opinions. Mina, an care assistant of Indian birth, is sometimes isolated because her grammar and syntax are difficult to understand, but she doesn't hesitate to expresses her sometimes quite idiosyncratic views. Both of them resist Robert's commitment in favour of the EU. They do not want change and they refuse to be told by the French what they should do. They do not want Britain to become similar to continental countries that they suspect to have no welfare state: 'Do the French have pensions?' asks Brenda, sincerely.

However, during the card exercise, the tone changed slightly. Their answers emphasize the power of big entrepreneurs and businesses, as well as politicians, in a way quite similar to the Set 2 Paris managers discussed above. The managers, though, said that 'the average guy' is losing, making it clear simultaneously with this displacement that they are this guy: 'Everyone but us' profits from Europe, says one of their cards. In the Oxford group, when the moderator reads the card 'government', Ron, Asian and Muslim, who works in a car factory and who remains silent for most of the discussion, answers first, probably because he was the one who wrote the card: 
Moderator (showing another card): government we've got here

Ron: cause they make all the decisions.

Brenda $=$ good one (Silence. We can hear the moderator writing the answer)

Mina: (With a move of her hand showing how evident this is and looking at the others) They got authority to make the decisions, power to make the decisions. Then people like us it's nothing. Whatever they want to do they all do it.

Ron: We are just a number

Brenda $=$ yeah

Ron (smiling, apparently satisfied with others approval): We're a dot. (Silence. They all seem to agree)

So they might want to keep Britain independent but they make perfectly clear that its power is not theirs: it is government and politicians' power, MPs who 'get big fat cigars, more trade, more profit'. The three group leaders reaffirm quietly this feeling of domination a few minutes later, when the moderator, after having read all the cards again, insists that they explain why 'the normal public' as Mina said, is losing:

Brenda: Power it's all about power isn't it. (Silence) We do what we're told really don't we? Mina (looking at Brenda): We have to follow whatever their rule they make.

Brenda: Yeah if they make a law we follow that law

Robert: Whether we like it or not.

Mina (smiling, incomprehensible utterance) ... so we have to follow their rule whatever they will make (Long silence, the moderator introduces the next question) The normal public loses because of government, and immigration is part of the explanation: business wants mobility and immigration because it lowers wages. The normal public suffers either, for British natives, because they do not earn enough money anymore and find it difficult to get jobs; or, for immigrants, because they have to leave their country if they want to find work and earn a bit of money. Entrepreneurs and politicians win, people suffer. 
The French workers also incriminate immigration but in a lower voice. Two of the women in the group are North African immigrants - the third is Black. This group was particularly lively, thanks to the constant, brave and humorous but sometimes chaotic interventions of Yasmina, a middle aged Muslim women, wearing a headscarf. She is unemployed and we contacted her through the Restos $d u$ Coeur, a meal centre. Instead of a frontal conflict on immigration, the discussion turned to a strong opposition between Yasmina and Habiba, who was also born in North Africa but is from bourgeois descent and owns a shop with her husband in the suburbs of Paris. They are opposed to each other on social integration. Yasmina claims that immigrants' children are victims of racism and cannot integrate, while Habiba blames their parents. This conflict is clearly quite remote from European issues and indeed the group tends to sidetrack. More precisely, they focus on what is happening in France, as France is said, from the beginning to be part of Europe and being European to belong to a European country. They share some degree of euroscepticism, but this is only loosely related to national sovereignty - apart from Lionel, a security guard, who suggests that the EU is a kind of 'mixed salad' viii European integration does not interest them because they consider major issues to be global. Moreover, they all agree that things are not going well, and as the EU has been in existence for a while this is proof that it does not work. Their discussion also resounds with a strong and shared feeling of disempowerment. They do not so much focus on politicians but evoke a globalised world dominated by the rich, a few people (they mention 'the 200 families', a traditional populist French image, and the 'barbarians of finance'), those who profit from everything to the detriment of people like them.

Once again, the Belgian workers, in contrast to the French and the British, demonstrate knowledge of how the EU works as a political system. This group, quite heterogeneous in terms of political sophistication, also gathers participants from North African and African descent as well as European. Immigration as well as the way immigrants are treated in Belgium are major topics. The ethnic minority members are openly eurosceptic, the others not. However, they know the EU exists and will remain. Europe as it should be, Europe as the ideal they have been told about, is still to come. Rose, a young receptionist, who suggests that her family is not Belgian (we guess it is probably Eastern 
European although she does not say explicitly) evokes a couple of times Europe as a dream of solidarity, a proper union that would make Europeans stronger. This group often mentions the US as a negative other. They all agree that if integration is going to happen -they also agree that it would take a long long time - the constituent European countries should remain as an origin and a source of identity and diversity. But identity means security in the most concrete sense of the term as Ali, a social worker who seems to be also a union leader, and whose influence on the discussion is strong, explains:

Ali : Yes, I would like to come back to what the young lady (indicates Rose) was saying about her identity. (Moderator says yes) It's really important to keep it I mean. We here, in Belgium, we are relatively happy to live considering our social security system. We have to keep it, more importantly we have to defend it because if...

Rose (interrupting): We should keep it of course!

Ali : We want a more generous system and, I don't know, that health costs are better reimbursed I would say. This is this kind of things we need to keep as Belgians here, in Belgium, there are the most positive things.

This group considers the market very negatively: free market means insecurity, it should be controlled, and people like them have to be protected. Belgium thus is the political community they refer to as it provides protection against unemployment and social security. However, as in the case of the Belgian employees, but more strongly, they all agree on the fact that they are currently paying for European integration. The cost of living has become intolerable for people like them. Like the French and the British workers, this is what matters, and European integration seems, by comparison, non-salient.

So a major difference between working class and employees groups on the one hand, and managers and activists on the other, lies in the salience of European issues. European integration is hardly an issue for the former while it is matter of debate and openly expressed conflict for the latter. Activists and managers overlook Europe as we hoped they would do in the sense that, during these three hours of discussion, they gave an overview of European integration. They discussed the consequences of the 
current state of integration and its future. They confronted each other on these issues, especially when the stances taken regarding the EU traced the lines of political cleavages such as economic liberalism versus state intervention, or cultural and religious heritage versus civic and democratic integration. Most of them defined themselves as European, although some of them explicitly differentiated between being and feeling European, and supporting the EU.

Workers and to a lesser extent employees, by contrast, overlooked Europe in the sense that they hardly paid attention to it. The French and the British clearly did not know much about it and this might also explain why they took every opportunity to change the subject. The Belgians were more knowledgeable. However, the EU is not an issue for any of them as they consider it as a done deal. The EU is there, it is somewhere - on the other side of the Channel, in the future, all around. It does not do particularly well, as all complain about the present situation and obviously, the EU has not prevented things from getting worse. But they do not identify it either as a particular source of power or a nuisance compared to what really damages society: constant change (newcomers, job market, education, currency, etc.), the failure of political elites (that nobody trusts) and globalisation. As workers and employees do not particularly care about the EU, it seems difficult to argue that their reactions to Europe put identity at stake. More particularly, we clearly see that (exclusive) national identity does not particularly fuel Euroscepticism on their part.

Conclusion: identity as a red herring.

Our project confirms both the enduring national and social differences in citizens' attitudes toward integration. Regarding the social gap, it neither confirms nor falsifies the thesis that working class people are more eurosceptic than elites. The number of cases we analysed, as well as the way we designed the groups and selected participants, does not allow any inference about this. However, as we put together eurosceptics and europhiles in groups, we are in the position to analyse the explicit and implicit arguments of participants when (if ever) they confront each other on European issues. In particular we can examine the arguments workers and employees use when they refer negatively to the 
EU. Our research design enables us to evaluate the salience of Europe issues, by examining the frequency and intensity of conflict within each category of groups. Lastly, we can analyse, when (if) conflict happens, what kind of 'perspective' is involved, what kind of 'us' they - workers, employees, managers and activists - construct in this interaction, if any. In the terms of the current debate in European studies, we can ask what kind of identity, if any, is at stake.

What mainly characterises workers and employees, in comparison with managers and activists, is their lack of interest in the topic of Europe. They express negative opinions, but these are not strong opinions, they are not stances taken against pro-European attitudes defended by others. They are reactions. Further, they are weakly related to declarations made in response to items in the recruitment and participants' questionnaires. They are reactive, also, to feelings on subjectively more important issues. It is important to stress that these negative opinions are not fuelled by exclusive national identification. First, the collective identity, the 'us' and the 'we' who do not profit from Europe, are not national but 'the average guys', the little, the poor, the 'numbers'. In this sense, our participants clearly articulate the view that Europe is a class project. Second, the idea that national sovereignty is limited by Europe hardly appears in the picture, as the EU is not perceived as an autonomous policy level. Workers and employees barely differentiate between national and European political leaders. In 1998, Anderson, using quantitative data, already found that:

'citizens predominantly rely on broad notions of diffuse support for democratic institutions as proxy for evaluating the integration process.' (Anderson 1998, 593)

Anderson further suggested that:

'If, as can be expected for the foreseeable future, attitudes towards domestic politics continue to play a key role in the formation of citizen's attitudes towards European integration, a sense of supranational community or identity as conceptualized by scholars such as Deutsch and Ingelhart may not be necessary to generate high level of integration support among the publics of the member states - so long as there is significant support for key domestic political actors and institutions' (Anderson 1998, 594). 
Clearly, our focus groups show that support for domestic political leaders is missing. It is missing notably because participants consider that national political leaders proved unable to protect citizens from globalisation. European integration appears in these focus groups as part and parcel of globalisation. They both profit politicians and the economy. European politicians are not distinguished from national ones, and firms that benefit the most are global.

This lack of support for national leaders might explain why, following Anderson, European studies are searching so hard for European identity. However, our results suggest that trying to account for the persistent elitist bias of European attitudes with identity is on the wrong track. It gives rise to normative comment, as being nationalist is obviously worse than being cosmopolitan - losers are condemned for being closed and the winners admired for being open. (eg Risse 2010) But, if there is a euro-clash, according to our groups, feelings of domination by their own national elites and political leaders is more likely to be responsible for it than any lament for lost sovereignty. Just as national and European 'governments' are not perceived as autonomous levels, European and national identities or identifications cannot be considered separately.

These focus groups also confirm both quantitative and qualitative findings in this respect: people feel European because they feel French, Belgian or British, not the contrary. It took time for European studies to acknowledge that national identification does not prevent citizens from feeling European (Schild, 2001; Diez Medrano \& Gutierrez ,2001; Risse, 2003; Citrin and Sides, 2004; Bruter, 2005). On the contrary, the "we" feeling constructed by national belonging, in an era of growing individualisation, is the template for European identification (Duchesne and Frognier 1994, 2002, 2008). Nevertheless, Eurobarometer surveys keep asking citizens if they feel more European or national, and European scholars keep using this question in order to explain attitudes towards European integration. But the question creates, for most respondents, artificial data (see Chapter One) and contributes to distortion in analysis of the connexion that European citizens are establishing with their new political community. These discussions among workers and employees, but also among managers and activists, confirm the results accumulated by qualitative research. ${ }^{\mathrm{x}}$ European identity, 
when citizens are concerned, is the wrong concept. In play is a long term process of Europeanisation of national identities that varies importantly depending on nationality and social class. Whether this process will end up with a European identity similar to current national identities is not anything that can be foretold. Perhaps we can say it is unlikely, as the context differs so widely from what it was when national identities were constructed.

The fact that our 2006 data confirm an observation made in 1998 does not mean that nothing has changed in the last 15 years. Hooghe and Mark's suggestion that a 'constraining dissensus' has developed over the last decades is not incompatible with our observations. If workers and employees do not care about the EU, this is not the case for activists nor (to a lesser extent) for managers. According to these discussions, the dissensus that constrains political leaders might not so much be the consequence of a growing identity conflict between lower and higher classes: it might rather be the reflection of elites' own dissensus about European integration.

But the major finding discussed here is the significance of indifference and non-interest regarding European integration in workers and employees groups in the three cities. The next chapter takes a closer look at participants who acknowledged from the beginning, in the recruitment questionnaire, that they did not have a fixed opinion on these issues. This lack of interest cannot be interpreted as a deficit - the same participants took clear stances on other issues that were more important to them. Our final substantial analytic chapter will go on to address the normative and theoretical understandings of representation and legitimacy that lie beyond euroindifference.

\footnotetext{
${ }^{\mathrm{i}}$ Fligstein uses a variety of data, but Chapter 5 is based on Eurobarometer; Hooghe and Marks, 2008 quote extensively from work based on Eurobarometer; Hooghe and Marks, 2004 is a Eurobarometer analysis.

${ }^{\text {ii }}$ Gamson's focus groups were organized in a participants' house, with acquaintances, so mimicked a natural setting.
} 
${ }^{\text {iii }}$ As a robustness check a second analysis, omitting codes that seem to play an important role but have only a small number of cases (eg USA, RICH, EXT,IMM) was run; the general configuration hardly changes.

${ }^{\text {iv }}$ On gender relationships in interviews and focus groups, Wilkinson 1998.

${ }^{\mathrm{v}}$ The full answer is 'new entering countries, leading sectors, developing countries » (les nouveaux entrants, secteurs de pointe, régions en voie de développement). Patrick and Michel ignored the rule: one card, one answer.

${ }^{\mathrm{vi}}$ Les élus is a generic term for any kind of elected person.

${ }^{\text {vii }} \mathrm{He}$ chose to use a nickname, as all participants might, although few did in Brussels, none in Paris.

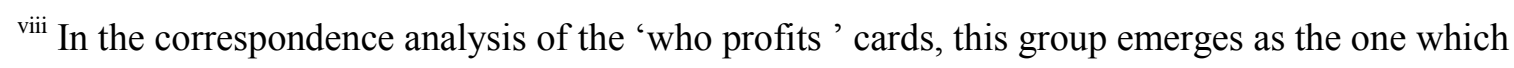
contributes most to Factor 1 at the 'profit' rather than 'benefit' end.

${ }^{\text {ix }}$ Confirmed by Kuhn (2011 p.826); 15 years later the lower one's satisfaction with national politics, the greater the likehood to say one's country membership is a bad thing (Kuhn 2011, 826)

${ }^{\mathrm{x}}$ See in particular Diez Medrano, Throssel and Weill in Politique Européenne 30, 2010. 